revista

tempos e espacos em educacão

\title{
"Paisaje crítico": narrativas visuales y formación de sensibilidades socio-bio-ecológicas frente a la crisis ambiental global
}

\author{
Juliana Enrico*
}

\begin{abstract}
Resumen
En el presente trabajo analizaremos el proyecto fotográfico denominado "Paisaje crítico", obra del artista visual Gabriel Orge (Córdoba, Argentina) leyendo la trama de algunas de sus incidencias en diversos espacios de la cultura, en tanto aporte a la formación de sensibilidades socio-bio-ecológicas y ecosistémicas desde un paradigma vital contra las violencias destructivas del capitalismo (sistema económico y social que depreda la naturaleza y los símbolos humanos asociados al espacio habitable de la tierra, volviéndolo funesto, inhabitable e inhumano). Frente a este sistema de muerte, las imágenes nos llegan "tocando lo real", como lo plantea DidiHuberman; manifestándose en sí mismas como ruinas vivientes.En particular, indagaremos una experiencia de trabajo escolar de reflexión, a partir de la visita a la muestra por parte de docentes y estudiantes de nivel primario del Instituto de Educación Córdoba.

Palabras clave: Fotografía. Sensibilidades ecológicas .Paisaje crítico. Gabriel Orge.
\end{abstract}

\footnotetext{
* Dra. en Ciencias de la Educación. Investigadora del Consejo Nacional de Investigaciones Científicas y Técnicas (CONICET) del Ministerio de Ciencia, Tecnología e Innovación Productiva de la Nación Argentina, con sede en el Centro de Estudios Avanzados (CEA) de la Universidad Nacional de Córdoba (CEA, UNC). Tema de investigación actual: "Transformaciones contemporáneas del espacio educativo-cultural argentino: articulaciones entre nuevos lenguajes, nuevas políticas y nuevas subjetividades históricas”. julianaenrico@gmail.com
} 


\section{"Paisaje crítico" (critical landscape): visual narratives and formation of socio-bio-ecological sensitivities with regard to the global environmental crisis}

\section{Summary:}

In this work we will analyze a photographic project named "Paisaje crítico" ("Critical Landscape"), work of the visual artist Gabriel Orge (Córdoba, Argentina), by reading the story of some of his incursions in different cultural spaces, as a contribution to the formation of socio-bio-ecological and ecosystemic sensitivities from a vital paradigm against the destructive violence of capitalism (economic and social system that preys on nature and human symbols associated with the earth habitable space, turning it ominous, inhabitable and inhuman). Faced with this system of death, the images come to us "touching the real", as Didi-Huberman puts it; manifesting themselves as living ruins. In particular, we will explore a school work experience of reflection, as a result of the visit to the exhibition by primary school teachers and students from Instituto de Educación Córdoba.

Keywords: Photography. Ecological sensitivities. Paisaje crítico. Gabriel Orge.

\section{"Paisagem crítico": narrativas visuais e sensibilidades na formação sócio-bio-ecológica para enfrentar a crise ambiental global}

\section{Resumo}

No presente trabalho analisaremos o projeto fotográfico denominado "Paisaje crítico" ("Paisagem Crítica”), obra do artista plástico Gabriel Orge (Córdoba, Argentina), lendo a trama de algumas de suas incidências em diferentes espaços da cultura, entendida como contribuição para a formação das sensibilidades sócio-bio-ecológicas e ecossistêmicas a partir de um paradigma vital contra a violência destrutiva do capitalismo (sistema econômico e social que deprava a natureza e os símbolos humanos associados ao espaço habitável da terra, tornando-a fatal, inabitável e desumana). Diante desse sistema de morte, as imagens nos alcançam "tocando o real", como diz Didi-Huberman; manifestando-se como ruínas vivas. Em particular, investigaremos uma experiência de trabalho escolar de reflexão, a partir da visita à amostra de professores e alunos do nível primário do Instituto de Educação Córdoba.

Palavras-chave: Fotografia. Sensibilidades ecológicas. Paisagem crítica. Gabriel Orge. 


\section{Poéticas frente a paisajes en crisis}

“... El corazón, si pudiese pensar, se detendría...” (Poema 1)

"Niebla o humo? ¿Ascendía de la tierra o descendía del cielo?

No se sabía: era más bien una enfermedad del aire que un descenso o una emanación. A veces parecía más una enfermedad de los ojos que una realidad de la naturaleza." (Poema 385)

Fernando Pessoa (como Bernardo Soares), Libro del desasosiego

Organizada por el Instituto Goethe a partir de una curaduría de Alfons Hug (Alemania / Brasil) y Paz Guevara (Chile / Alemania), quienes propusieron abordar en una videoinstalación colectiva internacional el tema de la "crisis global" del sistema capitalista mundial, la exposición denominada "Poetas en tiempo de escasez" -la cual integra Gabriel Orge ${ }^{2}$ con el proyecto fotográfico denominado "Paisaje Crítico"3 - es exhibida en el Museo Provincial de Bellas Artes Emilio Caraffa, Córdoba, en 2012.

Como lo menciona Hug en el texto inaugural -retomando la noción de Hölderlin para dar nombre a esta exposición- los artistas seleccionados presentan múltiples lecturas del mundo contemporáneo, asumiendo "un rol de sismógrafos" al captar el temblor de la tierra ("la violencia ejercida sobre la tierra", la llama Orge) a lo largo de países y continentes.

La propuesta sitúa la mirada artística en espacios, geografías, sociedades y contextos particulares y específicos que constituyen problemáticas y crisis locales, pero a su vez muestra la universalidad del fenómeno de destrucción global en diferentes escalas y trazos superpuestos. En este marco de diálogo de autoría colectiva -integrado por la videoinstalación de ocho artistas de diferentes países del mundo- Orge aborda el caso de Argentina, desde la crisis ambiental, económica y social que destruye y agrede formas sustentables y solidarias de vida y de comunidad.

El despliegue espacio-temporal de "Paisaje crítico" en tanto intervención cultural, al constituir una puesta en escena museográfica visitada por estudiantes y docentes, mani-

\footnotetext{
1 Participan del proyecto de "vide oinstalación colectiva internacional" los siguientes artistas: Chen Chieh-Jen (Taiwan), Julián D’ Angiolillo (Argentina), Harun Farocki (Alemania), Gianfranco Foschino (Chile), Oreste Lattaro (Argentina / Uruguay), Chris Larson (USA), Pablo Lobato (Brasil), Mark Formanek (Alemania), Gabriel Orge (Argentina), Roman Signer (Suiza), y Marcos Zimmermann (Argentina), bajo la curaduría de Alfons Hug (Alemania / Brasil) y Paz Guevara (Chile / Alemania). Museo provincial de Bellas Artes Emilio Caraffa. Córdoba, mayo a junio de 2012.
}

2 Gabriel Orge (Bell Ville, Córdoba, 1967) es fotógrafo y artista visual. Coordina junto a Álvaro Figueroa el taller de experimentación fotográfica denominado "Manifiesto Alegría", surgido en la crisis post 2001 en la Argentina, en un contexto de total deterioro económico y social del país. "La imagen (y sobre todo la imagen publicitaria) es como el sistema nervioso del sistema capitalista”, dice Orge (por tanto, se debe trabajar crítica y sensiblemente con la producción que genera este enorme dispositivo, pensando sobre todo en sus efectos discursivos y significantes).

$\mathrm{Al}$ explorar el tema profundo del instante y de la duración, en la fotografía de Orge hay un tipo de captura en la que se manifiesta la emoción que produce una temporalidad detenida y lenta que es necesario indagar en detalle hacia adentro de los elementos expuestos. Su muestra más reciente es "Apareciendo" (2014, en proceso), curada por Agustina Triquell y exhibida en el Museo Palacio Dionisi de Córdoba en marzo de 2018. Dentro de esta serie encontramos la fotografía "Apareciendo a López en el río Ctalamochita", Primer Premio Adquisición del Salón Nacional de las Artes Visuales (2015). Orge se ha dedicado además a fotografiar a personajes marginados y excéntricos, o queer; y a producir y circular imágenes y discusiones del campo de los estudios visuales que muestran la crisis social, cultural y económica contemporánea. Ver: https://latinta.com.ar/2016/09/gabriel-orge-sin-emocion-no-hay-proyecto-2/

3 "Paisaje Crítico" se compone de una serie de nueve fotografías digitales directas de 80 x $120 \mathrm{~cm}$. y 104 x $160 \mathrm{~cm}$., realizadas entre febrero y marzo de 2012. 
fiesta una preocupación del presente histórico que es abordada desde múltiples miradas en duelo (mediante una "aproximación más bien documental"): este cruce de miradas configura un campo de sensibilidades que es urgente sostener en nuestro tiempo frente a los vínculos de crueldad y daño que imponen los grandes sistemas de poder.

La obra registra documentalmente imágenes de destrucción, configurando un relato visual de efectos y huellas de la crisis y el daño ambiental global que va contaminando o destruyendo la ciudad y el paisaje, al tomar imágenes "en crudo" o con su propia luz natural, sin mise-en-scéne ni demasiado artificio técnico sino en el desenvolvimiento mismo de las cosas en su temporalidad y en su espacio cotidiano, capturadas en el instante en que se revelan a su misterio sin sombras, como diría Benjamin.

Pero más que "el instante decisivo" (tomando la noción de Cartier-Bresson) ${ }^{4}$, en este tipo de tomas sobre paisajes de temporalidad interna lenta lo que aparece captado es esa temporalidad casi detenida en la escena misma, "real", donde lo que verdaderamente ocurre de algún modo se esconde tras las imágenes superficiales que vemos (y aquí la noción de Benjamin de "inconsciente óptico" ${ }^{5}$ nos lleva al terreno de las sensaciones y de la memoria, que amplía las percepciones y significaciones producidas dentro de nuestro campo visual).

Ya no podemos "respirar el aura", dice el autor. La tesis benjaminiana de que la percepción sensorial de las comunidades humanas se va transformando a medida que cambia su modo global de existencia (en relación tanto con los despliegues de la naturaleza, como con los de la historia y los de la técnica en el sentido de techné o arte mismo de las elaboraciones materiales del hombre) implica que muy diversos sistemas de simbolismos y de interpretación -cambiantes y mediados técnicamente- dan forma al cristal que filtra la mirada y las emociones humanas.

Si desde la modernidad estamos en una situación histórica de pérdida de valor cultual o ritual del aura, que se afirma en tanto "aparición irrepetible de una lejanía" ( $c f r$. Benjamin: 2007: 98), el análisis benjaminiano sobre el aura de la naturaleza nos acerca a repensar esta noción en relación con la sociedad y la cultura de masas. "En una tarde de verano, seguir con calma el perfil de una cordillera en el horizonte o una rama que arroja su sombra sobre el que reposa: eso significa respirar el aura de esa montaña o de esa rama” [...] por eso “... 'acercar' espacial y humanamente las cosas es una aspiración tan ardiente de las masas actuales" (Benjamin: 2007: 99).

Ante esta in-experiencia generalizada del aura como forma de vivencia contemporánea, la imagen en tanto reflejo del mundo -frente al alejamiento de las cosas- nos acerca a la dimensión de proximidad de lo efímero (condición o forma de la presencia y la reproducción técnica-digital actual, mediada tecnológicamente). "Quitarle la envoltura a cada objeto" y "hacer trizas su aura" tal vez sea la única forma en que hoy podemos acercarnos a percepciones cada vez más olvidadas: nos pone frente a un mundo que quizás no conoceríamos de otro modo (y nos insta a estar ahí, tocando el paisaje "verdaderamente" con nuestros ojos, fuera de formas espectacularizantes de mediación y ficcionalización que ambiguan nuestra percepción de la realidad y nuestro contacto piel a piel).

4 Aunque también aparece este registro de lo efímero en el caso de las quemas e incendios, por ejemplo (donde un minuto más tarde puede no quedar nada). Ver Figura 2.

5 Tanto como la de "inconsciente estético" en Ranciére, que mencionamos unas líneas más adelante. 


\section{Miradas impresionadas}

Analizaremos algunas apropiaciones semánticas y pedagógicas de esta intervención en una experiencia del Instituto de Educación Córdoba, consistente en la visita a la muestra y posterior trabajo en clases entre docentes y estudiantes de nivel primario; a tales fines, interrogaremos los usos de narrativas visuales en el marco de dispositivos culturales y pedagógicos críticos (en los que se entrecruzan, en este caso, la mirada artística, la mirada educativa y nuestra propia mirada "impresionada" o emulsionada por ambas experiencias).

Frente a los efectos más devastadores de la economía capitalista a gran escala (como el cambio ambiental global y la destrucción de formas de vida diversas, convivientes y sustentables, lo cual afecta desde grandes espacialidades biológicas o amplios espectros territoriales, hasta vidas puntuales en la pequeña escala microfísica de cada existencia vital; desde el paisaje en tanto derecho ambiental y en tanto macrocosmos humano, hasta cada pequeña gota de vida que tiene lugar en el mundo), nos interesa enfocarnos en el análisis de contra-imágenes y contra-discursos ${ }^{6}$ que se oponen al sistema hegemónico de destrucción global, intentando preservar a su vez los microcosmos vitales -de gran fragilidad- que dan sustento a la diversidad de formas de vida y de convivencia que forman nuestro mundo humano y no humano ${ }^{7}$. El arte, desde esta perspectiva, es el espacio por excelencia en el que por los siglos de los siglos se intenta elaborar y comprender social y culturalmente la violencia más allá de "definiciones" y nociones explicativas, llegando a tocar nuestras más profundas emociones y experiencias; siendo que el lenguaje artístico -mediante su retórica y su metafórica visual,

6 Como la mirada del arte crítico y las miradas de la infancia.

7 Sobre las discusiones entre el mundo humano y no humano; y entre la animalidad humana y no humana, lo cual implica pensar las intervenciones del hombre en / sobre / contra el mundo en torno de "cierta ley" o "no ley" (que supone el asedio silencioso de algo monstruoso o fantasmal que amenaza con destruirlo todo, como lo encarna en las literaturas clásicas universales la figura del lobo), ver Derrida, Seminario La bestia y el soberano (2010). En esta reflexión en la que Derrida piensa figuras animales en tanto figuraciones de lo político (distinguiendo con extrema sutileza que "la bestia no es exactamente el animal") nos interesa especialmente ver su análisis del énfasis en el carácter silente, sigiloso, casi invisible de las formas más extremas en que la violencia aparece tendiendo su manto sobre el mundo (como toda hegemonía y todo poder que, una vez articulados y desplegados en una economía y en una sociedad, simplemente transcurren en silencio, o en pleno ruido que se vuelve "natural del lugar" mientras "avanza a paso de lobo”). Dice Derrida: “... 'a paso de lobo’, que en general significa una especie de introducción, de intrusión discreta, incluso una especie de fractura inaparente, sin espectáculo, casi secreta, clandestina, una entrada que hace lo que sea para pasar desapercibida y, sobre todo, para no dejarse detener, interceptar, interrumpir. Avanzar 'a paso de lobo' es caminar sin hacer ruido, llegar sin prevenir, proceder discretamente, de forma silenciosa, invisible, casi inaudible e imperceptible, como para sorprender a una presa..." (Derrida, 2010: 20). Retomando a Zaratustra, "uno de los más ricos bestiarios de la filosofía occidental", donde Nietzsche expresa que en la más silenciosa de todas las horas está el mayor peligro: "Son las palabras más silenciosas las que aportan la tempestad", Derrida analiza en estas figuraciones animales (y en sus traducciones al espacio de la zoopolítica) la complejidad de los "espinosos problemas fronterizos" que nos plantean las traducciones idiomáticas y culturales de las figuras del lobo (tan presentes en las historias y en las literaturas de todo el mundo) en diferentes geografías, culturas y épocas -no hay lobos en todas partes, y no es lo mismo la experiencia de los lobos en Alaska que en medio oriente; ni en la Edad Media que en la actualidad, dice-. Es importante afirmar que... "Los lobos reales atraviesan, sin pedir autorización, las fronteras nacionales e institucionales de los hombres y de sus Estados-nación soberanos; los lobos en plena naturaleza, como suele decirse, los lobos reales son los mismos más acá o más allá de los Pirineos o de Los Alpes; pero las figuras del lobo pertenecen, a su vez, a culturas, naciones, lenguas, mitos, fábulas, figuraciones, historias." (Derrida, 2010: 23). El asedio, entonces, aparece y acontece de múltiples formas (aunque "no se vea claramente"), y la figura del "lobo suelto" se multiplica en el espacio social contemporáneo.

También en Barthes (2003) encontramos estas referencias -pensadas desde la perspectiva de la historia del arte- en las representaciones de la animalidad en tanto "infra-naturaleza", bajo figuras bestiales y feroces, monstruosas y demoníacas (frente a una naturaleza humanizada por la mirada cultural). Existe, plantea Barthes, una "abundancia figurativa en la pintura" donde podemos ver este tipo de representaciones animales bestiales, ligadas a las vivencias, sensaciones y sentimientos “... de la agresividad, el miedo, el apetito, la carne: el hombre sin ley" (cfr. Barthes, 2003: 75). Refiere aquí a los ineludibles trabajos de Gilbert Lascaux, el crítico de arte francés (Le Monstre dans I' art occidental, 1973); y a los de Jurgis Baltrusaitis, historiador del arte francés, de origen lituano (Le Moyen Art fantastique, 1988). 
lexical, plástica- adquiere jerarquía epistemológica (cfr. Boria, 2016) al conectar la multiplicidad y complejidad de diversas formas de conocimiento del mundo. ${ }^{8}$

Situado en el marco territorial de las problemáticas ambientales locales de Córdoba en la actualidad, Orge busca capturar y mostrar imágenes ("marcas de la crisis ambiental global que deja ver la ciudad") que se manifiestan sobre la urdimbre de un mismo proyecto global de sistemática destrucción, afectando al mundo, a las sociedades y a los sujetos en sus dimensiones universales, particulares e individuales necesariamente entrelazadas en su sitio, locus, bios (en el sentido de escalas de análisis y de espacios, territorios y cuerpos vivientes concretos). Así, "Paisaje crítico" nos enfrenta con sutileza a imágenes del daño ambiental y social (donde la dimensión del daño se reconstruye "por un saber" que articula otras narrativas, y no por el mirar hacia una imagen que aparece como "apacible" en su superficie; es decir: donde el daño es casi imperceptible visualmente y debe implicar una elaboración narrativa compleja $)^{9}$. Por otro lado, nos enfrenta de modo directo a imágenes del momento mismo de la destrucción y la violencia manifiestas (donde el mirar registra icónicamente el daño, y el movimiento suspendido de una pérdida irreparable). ${ }^{10}$

Orge nos pone de frente este tipo de imágenes directas, y nos da a pensar diversas formas (más o menos explícitamente violentas) de las sistemáticas destrucciones del mundo capitalista, visibles o invisibles; pero la serialidad narrativa visual trama una visibilidad y una manifestación enunciativa (situada en el punto de vista desde el que se inscribe el relato) que denuncia las formas ocultas de una violencia silenciosa junto a la violencia cruda y literal. La intención que sostiene la obra se relaciona con una pregunta central del archivo cultural: ¿qué es necesario mirar y fotografiar ahora mismo? ¿qué es urgente documentar? ¿qué denunciar de un más allá de la superficie de la imagen?

\section{Materialidades sensibles - paisajes habitados}

El cruce entre educación y estética aborda la compleja relación entre lenguajes, tecnologías, formas expresivas y formas de conocimiento, al articular dentro de dispositivos

\footnotetext{
Sería interesante trabajar la noción de "crisis global" -e incluso nombrarla como destrucción ecológica y ecosistémica global, que es lo que es aunque sea reducida al significante de un "modelo de desarrollo económico"- a partir de estas figuras monstruosas sigilosas (in-humanas, porque violan el contrato social "proteccionista") que portan la destrucción y se naturalizan como indestructibles e intransformables (la máquina del capitalismo aparece en tal sentido como trans-histórica, y no permite imaginar otro sistema de producción distinto, sustentable y viable, ya que además destruye todo intento de diferencia, antagonismo o interrupción a su lógica total: es el principio más fuerte de su identidad totalitaria). Quizás ante y desde la eufórica potencia de los niños y la infancia -lo verdaderamente indestructible- (y desde la mirada del arte crítico, sin dudas) es posible pensar con seriedad y profundidad estas transformaciones, desde un punto de vista humanista (o desde el marco -o punto de vista- del animal humano humanizado). Orge registra y nos muestra estas imágenes de la destrucción global, situándolas entre problemáticas concretas del presente (económicas, sociales, culturales) y desata un diálogo entre miradas sensibles al daño ambiental global (situado en el nudo mismo de los debates del arte contemporáneo). A su vez, las docentes se inscriben en este punto de vista, y nos "dan a ver" desde otras mediaciones (culturales y pedagógicas; tales como la visita al museo y el paseo escolar, y el análisis y producción colectiva en el aula) el trabajo mismo con la materia curricular y la elaboración de diferentes miradas adultas -que van a incidir entre los relatos de configuración de infancias y sujetos críticos- cruzadas directo a los ojos con las miradas de los niños.

8 Por ejemplo, analiza Boria - tomando una cita literaria de El corazón de las tinieblas, de Joseph Conrad -, el arte ordena las tramas de nuestros sentidos dado que encontramos en sus formas "... un principio de coherencia que organiza una gnosis, pero también una transmisión de emociones y percepciones” (Boria, 2016: 120)

9 (Ver Figuras 1 y 4 ).

10 (Ver Figura 2).
} 
formativos propios del espacio escolar -y dentro de diferentes dispositivos de formación y transmisión cultural en el espacio social más amplio- una diversidad de planos de la experiencia social y subjetiva. Así, la apertura de "regímenes de visibilidad" y la "configuración de la experiencia sensible" (Serra, 2012) en torno de los sentidos y emociones, traman caminos que consolidan formas de vida y de convivencia en las que el acceso a contenidos comunes y compartidos contribuye a una "justicia curricular" (Terigi, 2012) cuyos temas centrales no son sólo escolares sino que, a través de las artes, se desplazan hacia "referentes extramuros" que habilitan otras miradas hacia el mundo de la cultura y los problemas de nuestro presente; y se desplazan, incluso, hacia zonas de "saber" menos traducibles al lenguaje lógico-conceptual (y menos "comunicables" o "pedagogizables"), cercanas al territorio del "inconsciente estético" conceptualizado por Ranciére, pleno de imágenes -las cosas que tocan el corazón o la piel difícilmente pueden llegar a expresarse con palabras de modo consciente, aunque se clavan en la memoria y constituyen transmisiones memoriales-.

$\mathrm{Si}$, como lo analiza Serra tomando la noción de Godard que elabora Ranciére en relación con el cine, su virtud proviene de ser una gran tela extendida en la que el mundo se imprime, esta impresión se relaciona profundamente con la idea de educar en el sentido de dejar marcas, huellas, improntas ( $c f r$. Serra, 2012: 121) que afectan la propia mirada pedagógica y tiñen sensiblemente la experiencia. En este sentido, la temporalidad detenida de la fotografía nos insta a elaborar narrativas en las que estos afectos y marcas nos liguen de modo significativo a la experiencia de nuestra comunidad y de nuestro tiempo (porque, finalmente, no vemos sino con otros que sostienen nuestra propia mirada).

Qué mirar, de qué modo, con qué sentimientos e interrogando cómo pensarlo juntos atravesando el paisaje: esta perspectiva forma también una lengua visual, una ideología y una ideografía propia de una comunidad que mira -a la vez- el mundo, abriendo o cerrando los ojos ante la luz que define los cuerpos en su visibilidad.

Una emoción fría atraviesa la espacialidad de los paisajes en ruina en la serie de fotografías que constituyen el proyecto "Paisaje Crítico" de Gabriel Orge. Por mirar o por saber, nos producen una cierta tristeza.

Alfons Hug, en el marco de su curaduría de la instalación "Poetas en tiempos de escasez", expresa:

Paisaje Crítico es un proyecto fotográfico especialmente desarrollado para esta exposición, para el cual Gabriel Orge recorrió la ciudad de Córdoba y el interior del país con su cámara, retratando distintas formas de producción local que han surgido como consecuencia de la crisis global y el sistema capitalista: el desmonte para el cultivo de soja, el trabajo precario, los mecanismos alternativos de supervivencia, la economía paralela y la inmigración. Las fotografías de Orge representan un paisaje en transformación; por un lado explotado, quemado, cercado, y por otro precariamente ocupado por asentamientos provisorios. El paisaje, que implica un sujeto observador y un terreno observado del que se destacan sus cualidades, se revela en este proyecto desde la mirada de Orge como un paisaje en crisis y, además de natural, como un paisaje socio-cultural donde ver las desigualdades económicas y sociales. ${ }^{11}$ 
Como lo afirma Orge, "el paisaje es el hombre en relación con el espacio"12.

Rastreando un análisis sobre la historia de la noción de "paisaje" que realiza Maderuelo $(2005,2006)$ desde la perspectiva de la historia de la cultura, este concepto surge en el ámbito del arte para designar un género pictórico -cobrando un sentido pleno en la actividad de la pintura en Occidente-, extendiéndose luego sus usos a otros espacios del arte y a una diversidad de prácticas culturales. No siendo el paisaje asociado en términos de sinonimia semántica a la naturaleza, ni al medio físico natural que nos rodea (o "entorno real" exterior) alude más bien a la representación en imágenes de ese entorno material, por medio de simbolismos y figuraciones sensibles de muy diversas texturas.

En medio de todo el arco objetivo - subjetivo que implica pensar los usos y prácticas representacionales figurativas o abstractas en torno de esta noción (desde el paradigma de las ciencias naturales, el positivismo geográfico-científico, la topografía, la cartografía, la biogeografía, la ecología; hasta la aparición de la noción de landscape en la pintura holandesa, y sus posteriores usos en la pintura y en la fotografía en tanto registro histórico-documental (impresionista), o en tanto "visión", "contemplación" y expresión de una "atmósfera" sentida, natural o artificial; ya no en tanto "fondo" sino perceptible como "presencia" viviente con un estatuto elemental y compositivo complejo y fundamental; desde la visión territorial, política y económica del espacio -analógica, proporcional, exacta o "coincidente" con un cierto recorte analítico "objetivo", medible científicamente en términos de estrategias y recursos materiales empíricos concretos- hasta la mirada cultural y artística, atravesada por los instrumentos, técnicas y desarrollos científicos y tecnológicos del siglo $\mathrm{XX}$, que permiten no tanto re-producir el paisaje sino re-crear las imágenes y sentidos del entorno, e incluso intervenir y des-materializar sus impresiones sensibles más naturalizadas: desde ambos tipos de lecturas podemos acercarnos a una noción de "paisaje" en tanto "espejo del mundo" $y$ "anamorfosis" (o imagen trans-figurada que se deforma y cambia según desde dónde la miramos): memoria o huella sensible respecto de una supuesta imagen original positiva que debemos atesorar. Dice el autor:

Geógrafos y artistas han conseguido ofrecer visiones paisajistas del mundo antes de que el resto de los humanos fueran capaces de descubrir en los entornos lo que éstos tienen de paisaje. Las primeras representaciones cartográficas y pictóricas empezaron a mostrar unas realidades que hasta entonces eran imperceptibles, haciendo evidentes, a la vez, los objetos y su representación, de tal manera que la representación hace emerger el objeto, lo que quiere decir que no hubiéramos llegado a tener conciencia paisajista sin la existencia de los mapas y los cuadros por medio de los cuales hemos podido comprender muchas de las cualidades que posee el territorio en cuanto paisaje.

Hay que hacer notar que, desde el siglo XVI, muchos artistas, como Antón van den Wingaerde, Peter Bruegel o El Greco y, más tarde, los vedutisti, con Canaleto a la cabeza, trabajaron como topógrafos, cartógrafos y cuadraturistas, haciendo que mapas y vistas topográficas adquirieran unas calidades plásticas que permiten

12 Fuente: Nota "Belleza en el drama", por Verónica Molas. Suplemento "Vos" del diario La voz del interior (Córdoba), publicado el 20/11/2013. En: http://vos.lavoz.com.ar/artes/belleza-drama (Consultado: 07/03/2018). En su taller, Orge también expresa: "El paisaje está en la mirada". 
que en la actualidad se contemplen esos trabajos no sólo como piezas técnicas o históricas sino como auténticas obras artísticas. (MADERUELO, 2006: 12-13). ${ }^{13}$

Así, el pasaje al mundo de las sensaciones y las emociones en la configuración del paisaje (en tanto conceptualización y en tanto emoción a la vez) conforma todo un campo de trabajo entre diversas materialidades a analizar y pensar: el paisaje construido en tanto "mundo objetivo" amenazado en su permanencia espacio-temporal (objeto geo-político y bio-político de escala universal o global, desde un enfoque ecológico y biológico); y el paisaje en tanto "sueño del mundo" e imagen del habitar humano en su convivencia con una multiplicidad de otros seres vivientes, en territorios y comunidades específicos que le dan sustento y posibilidad de existencia (desde un enfoque cultural, social y ecosistémico situado). El cruce profundo entre la sensibilidad científica, la sensibilidad artística y la sensibilidad del habitar localizado en sí mismo -llámese territorios, economías y comunidades locales, saberes y economías del campo popular, experiencias territoriales, hogar, refugio- quizás sea nuestra única esperanza para preservar nuestra naturaleza y nuestras culturas, la tierra y sus recursos vitales mediante formas de vida sustentables. Esto implica un mirar juntos, bio-diverso, divergente y en deriva pero hacia horizontes espaciales y temporales comunes, donde podamos habitar juntos, menos expuestos al hambre, las injusticias, la depredación, las violencias, la intemperie y la destrucción y peligro de extinción crecientes (de territorios, paisajes, especies, pueblos, vidas, lenguas).

\section{El derecho al paisaje}

En su búsqueda Orge recorta del continnum espacial de la ciudad imágenes icónicas de la crisis global, que representan condensaciones específicas o magnificentes del daño producido por el modelo de desarrollo capitalista industrial (extractivo, desigual, contaminante, depredador, destructor, "ecocida"), con foco en el territorio de Córdoba. ${ }^{14}$

\footnotetext{
13 Nuestros resaltados.

14 Desde el punto de vista jurídico, debemos recordar que la Convención Europea del Paisaje del año 2000 establece: "el paisaje es parte del territorio tal y como es percibido por sus poblaciones" (incluyendo esta noción los complejos conceptos de ambiente y cultura). Es necesario también recordar que, en el marco de diversos acuerdos internacionales, y en términos de la consideración del paisaje como un bien jurídico protegido, la Constitución Nacional Argentina establece en el Artículo $41^{\circ}$ : “Todos los habitantes gozan del derecho a un ambiente sano, equilibrado, apto para el desarrollo humano y para que las actividades productivas satisfagan las necesidades presentes sin comprometer las de las generaciones futuras; $y$ tienen el deber de preservarlo [...] Las autoridades proveerán a la protección de este derecho, a la utilización racional de los recursos naturales, a la preservación del patrimonio natural y cultural y de la diversidad biológica, y a la información y educación ambientales." La Ley Nacional General de Ambiente 25.675/02 establece en su Artículo $4^{\circ}$, bajo el "Principio de equidad intergeneracional" (entre otros principios como el de prevención, precautorio, de responsabilidad, de progresividad, de solidaridad, sustentabilidad, etc.): “... Los responsables de la protección ambiental deberán velar por el uso y goce apropiado del ambiente por parte de las generaciones presentes y futuras." (en tales sentidos, los Artículos 14 y 15 refieren a la Educación Ambiental); ver asimismo la Ley Nacional No 26.331/07 de Presupuestos Mínimos de Protección Ambiental de Bosques Nativos. En Córdoba rige la Ley 10.208/15 de Política Ambiental de la Provincia de Córdoba, en adhesión a la Ley Nacional. La actual Ley Provincial N ${ }^{\circ}$ 9814/10 de Ordenamiento Territorial de Bosques Nativos de la provincia de Córdoba -llamada "Ley de Bosques"- en pleno conflicto por su intento de modificatoria en 2017 y ante una devastación creciente y desmedida del monte nativo dados los necro-negocios agroforestales -sobre todo las plantaciones de soja- e inmobiliarios; la falta de controles y la connivencia de los poderes públicos- establece en su Artículo $2^{\circ}$ (incisos c, d y e), en relación con el ordenamiento de bosques: "c) Implementar las medidas necesarias para evitar la disminución de la superficie ocupada por los bosques nativos de acuerdo a lo establecido en la Ley Nacional № 26.331; d) Disponer los mecanismos necesarios a fin de promover el incremento de la superficie total y calidad de los bosques nativos y mantener a perpetuidad sus servicios ambientales; e) Procurar el mantenimiento de la biodiversidad y de determinados procesos ecológicos y la mejora de los procesos sociales y culturales en los bosques nativos como fuente de arraigo e identidad para sus habitantes". La normativa puede consultarse en: http://ambiente.gob.ar/normativa-ambiental/
} 
$\mathrm{Si}$, a su vez, el territorio puede definirse como "efecto de la acción de una comunidad", nos interesa especialmente indagar este vínculo entre fotografía, memoria y territorio en la clave de una teoría del espacio social (marco de tensiones entre las culturas, la naturaleza, el mundo percibido y el mundo vivido en tanto experiencia e imagen que se proyecta hacia el futuro, a través de rastros y huellas de unas cicatrices sobre otras que nos llevan a explorar la dimensión del daño más manifiesto de las industrias de la explotación y la muerte sobre nuestros cada vez más precarios sistemas de vida contemporáneos).

Figura 1 - De la Serie "Paisaje crítico": Lote de soja

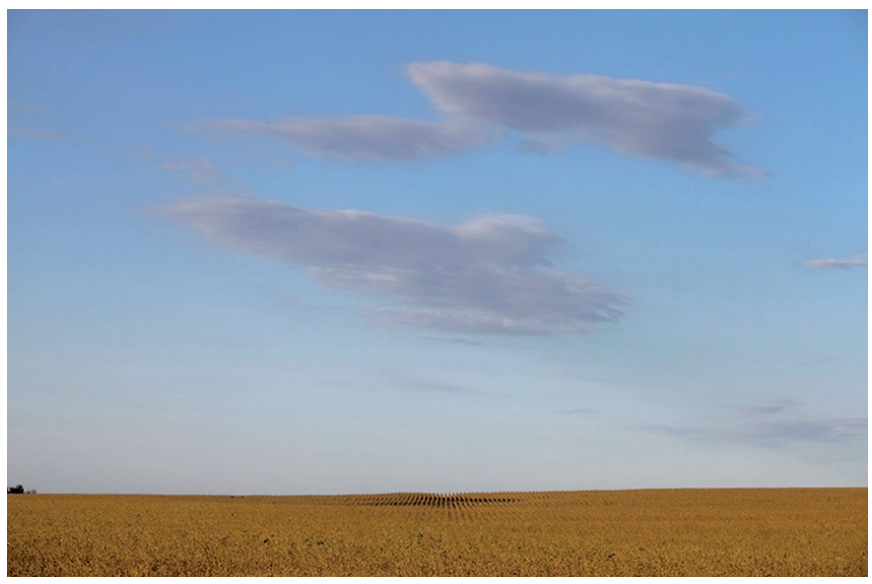

Gabriel Orge, 2012

En la serie de fotografías de Gabriel Orge vemos la imagen de un "campo dorado" de soja a punto de ser cosechada, cuadro sereno en pleno equilibrio y "calidez". Sobre esta fotografía Orge expresa en torno de su búsqueda: "Un paisaje apacible esconde algo atrás". Tal afirmación nos lleva a explorar todos los contornos mortíferos del modelo extractivista, poniéndole contenidos visuales y contextuales a los datos de la explotación agroforestal de la zona centro de la Argentina, cuyas principales problemáticas giran en torno al monocultivo masivo de soja transgénica, el envenenamiento por herbicidas y pesticidas como el glifosato, la destrucción de los suelos y de la fertilidad de la tierra, la agroexportación de granos a precio de divisas internacionales en un país hambreado, y la realidad de pueblos envenenados allí donde predomina el negocio de la soja. Ésto sería una parte ínfima del "detrás" de esta imagen apacible llena de luz solar, cuyo trasfondo silencioso es el sistema de la tanatopolítica. ${ }^{16}{ }^{-17}$

15 Trabajamos estos contenidos en un taller de Manifiesto Alegría, dictado y coordinado por Gabriel Orge -con colaboración de Clara Johnston- entre septiembre y octubre de 2017.

16 Sobre este concepto -o la bio(tanato)política- y sobre la indistinción derrideana de "la-vida-la-muerte", ver Svampa, Antonelli (2009); Biset, (2012); Antonelli (2016).

17 Retomando las nociones de De Souza Santos (2013) y de Harvey (2007) sobre el neo-extractivismo y la acumulación por desposesión, lógicas propias de la economía global capitalista, Antonelli analiza estos efectos desde la perspectiva del Sur Global. Según el análisis de Sassen (2015) en relación con su concepto de "formaciones predatorias", la autora expresa en su mirada sobre los territorios violentados, con "campos sin campesinos", por ejemplo (típica imagen de las plantaciones de soja), que aparecen cada vez más “las pinturas negras del mundo, las plagas, las pestes”... "el discurso de Sassen propone ver agujeros de la biósfera para inscribir las tierras muertas, las aguas muertas, el acaparamiento de tierras, los huecos poblacionales que devienen en cuerpos suspendidos (o encerrados)..." (cfr. Antonelli, 2016: 72 - 73). Alejándonos lo suficiente para mirar la tierra desde el espacio, pueden verse y captarse mediante imágenes satelitales estos huecos sin vida dispersos sobre el planeta, verdaderos páramos muertos cuyas huellas dañan y devastan para siempre el territorio. 
"Paisaje crítico" - "Contra-fuegos" (o una mirada que insiste en encender fuegos contra los incendios)

El proyecto denominado "Paisaje crítico" se inscribe en la reflexión postulada en la muestra "Poetas en tiempos de escasez", y es exhibido un año después en la Casona $\mathrm{Mu}$ nicipal de Córdoba, donde es visitado por estudiantes y docentes.

Gabriel Orge, cuyo registro y obra visual se centran fundamentalmente en la provincia de Córdoba, parte de inscribir la noción de "crisis global" en torno a ejes de destrucción ecosistémica, los cuales enumera como: la quema y el desmonte; el cultivo de soja; la contaminación ambiental; la especulación inmobiliaria; la inmigración; el trabajo precario; la desigualdad y la fragmentación social.

Estas problemáticas son propias de las lógicas de funcionamiento del sistema económico y cultural extractivista contemporáneo a nivel mundial -y en América Latina en especial-, basado en la indistinción derrideana entre "la-vida-la-muerte" (Bisset, 2012; Enrico, 2015) que produce estructuralmente lo que Butler (2006) denomina vidas precarias.

Desde tal mirada, Orge trata de traducir en imágenes fotográficas la relación conceptual y formal entre paradigmáticas "escenas" de destrucción (del paisaje, del territorio, de la humanidad, de los lazos sociales, de la infancia).

Figura 2 - De la Serie "Paisaje crítico": Quema y desmonte

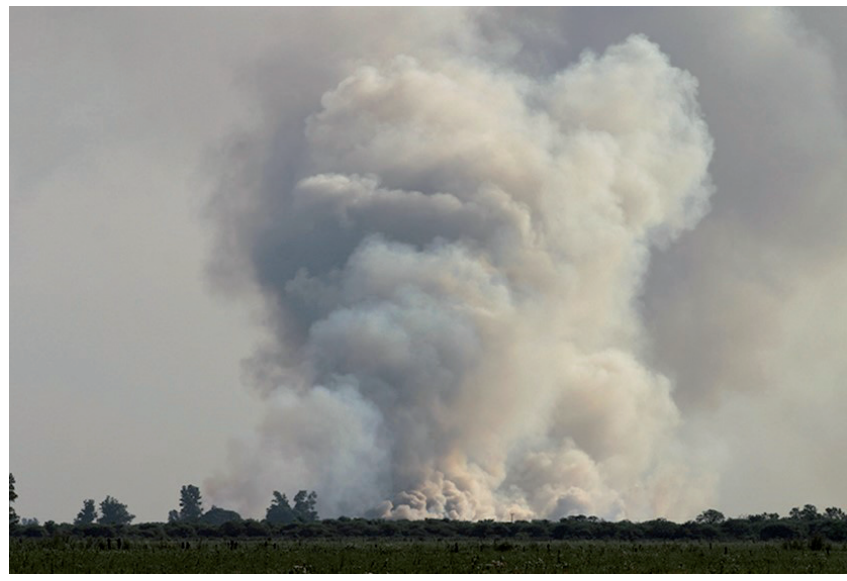

Gabriel Orge, 2012 
Figura 3 - De la Serie "Paisaje crítico": Inmigrantes bolivianos (en un cortadero de ladrillos)

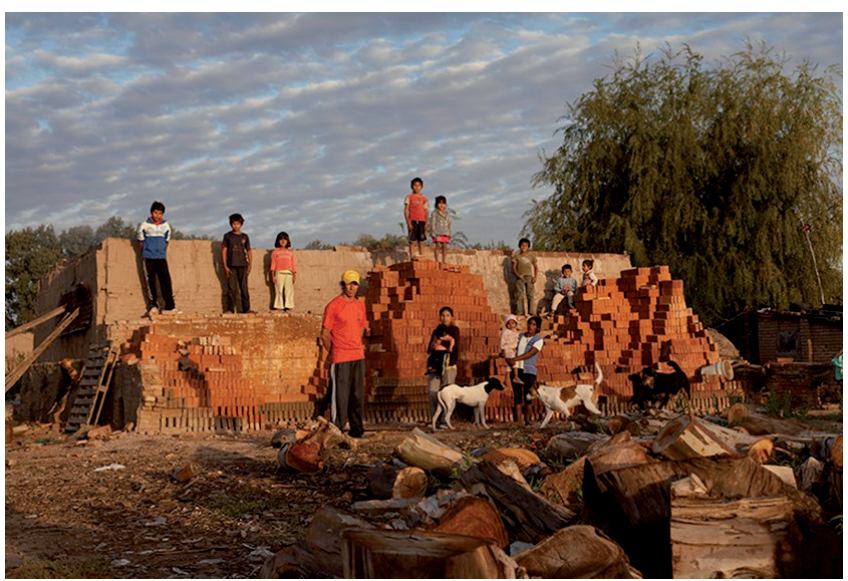

Gabriel Orge, 2012

Sin dudas la función social de la fotografía tiene un gran valor al producir imágenes sinestésicas (Kristeva, 2005) que nos conectan con la región de las sensaciones exploradas, vistas, conocidas. Tal como lo plantea Kristeva en su análisis de la teoría estética proustiana, no se puede escindir la sensación del recuerdo (en tanto la sensación nos "impresiona”; es decir que imprime -en los ojos, en el cuerpo, en la conciencia-imágenes sentidas. Y aquí lo interesante es que la fotografía en su límite mismo entre documentación y estetización (en cuanto a sus formas retóricas) se expone por fuera de las lógicas del arte burgués, mostrando la operación de un ojo que más que ver-mirar-captar instala una zona de mirada compartida, y nos induce a mirar más allá y juntos (hacia un fondo o reverso connotado cuya textura despliega historias de destrucción y naturalización que nos afectan a todos: "punzantes", como diría Barthes).

Alumnos de nivel primario del Instituto de Educación Córdoba visitaron la muestra "Paisaje crítico" y luego reflexionaron en sus clases (mediante el dibujo y el trabajo de análisis con sus docentes) sobre los temas y contenidos de la serie fotográfica. ${ }^{18}$

Partiendo de este abordaje "entre lenguajes", nos interesa resaltar la importancia de este tipo de dispositivos críticos -artístico-culturales, escolares y extraescolares- en la formación de sensibilidades socio-bio-ecológicas y ecosistémicas (pensando en la urgencia del trabajo actual y futuro sobre nuestras cada vez más frágiles y desiguales condiciones de existencia en el mundo, desde una concepción amplia del espacio vital humano y desde específicas condiciones de vida situadas).

Frente a la insensibilidad de la maquinaria capitalista, la mirada sensible de los niños, que expresan su conmoción frente a la destrucción, interpone otras imágenes del futuro ante un presente que declina sus tesoros ecosistémicos más hondos, destruyendo el equilibrio vital entre las comunidades y los territorios; la biodiversidad, la sustentabilidad y la felicidad.

18 Ver referencias en el video editado por Cecilia Pasquini, con música de Diego Clark. Disponible en: https://projeqt. com/cecipasquini/paisaje-cr\%C3\%ADtico/paisaje-cr\%C3\%ADtico/l; https://www.youtube.com/watch?v=wSdA4pcTrr0. Las docentes a cargo de esta experiencia (junto con sus alumnos) son Candelaria Jaimez y Marta Cañete Gallardo; quienes además realizan diferentes intervenciones -en la ciudad de Córdoba y en espacios diversos- en el marco de proyectos de educación artística-plástica-poética-visual. 
Realizada la intervención de Orge en la muestra "Poetas en tiempos de escasez" curada por Alfons Hug (que se exhibe en el Museo Caraffa en 2012), en el transcurso del año siguiente Orge produce la muestra "Paisaje Crítico", que es exhibida en la Casona Municipal de la ciudad de Córdoba en 2013. En la nota "Belleza en el drama"19 expresa que, luego de esta experiencia y en función de la propuesta de Hug, sale a recorrer en bicicleta la ciudad, buscando unir trazos (rastros, trazas, huellas) del desastre de la crisis ambiental global en su dimensión fenoménica -o visible en estado crudo-: hilos de espanto que urden una destrucción literal, ostentando un poder de depredación sin límites.

En ese camino -menciona la autora de la nota-

... Orge continuó pensando en el territorio como efecto de la acción de una comunidad: el desmonte para el cultivo de soja, el trabajo precario, los mecanismos de supervivencia, la inmigración. Y se encontró, además, con una extraña imagen de la contaminación ambiental cerca de la Circunvalación, en una laguna cercana al cementerio de San Vicente. 'Cuando les da el sol, las botellas se encienden', dice cuando señala lo que parecen de lejos pequeñas flores silvestres, en una de las nueve grandes fotografías de la muestra Paisaje crítico. ${ }^{20}$

Si siguiéramos esta metáfora biológica, parecerían flores que van a morir, pero no en el marco de su ciclo de vida, sino en el marco de un ciclo de muerte, producto del artificio destructor humano que cambiará o torcerá su destino de muerte natural: morirán envenenadas. Pero tampoco son flores, en verdad, y la metáfora es mórbida en sí misma: son basura sembrada en un lago totalmente contaminado, que enferma de mortalidad todo lo que toca.

Figura 4 - De la Serie "Paisaje crítico": Laguna y botellas (laguna contaminada con botellas, plástico, algas).

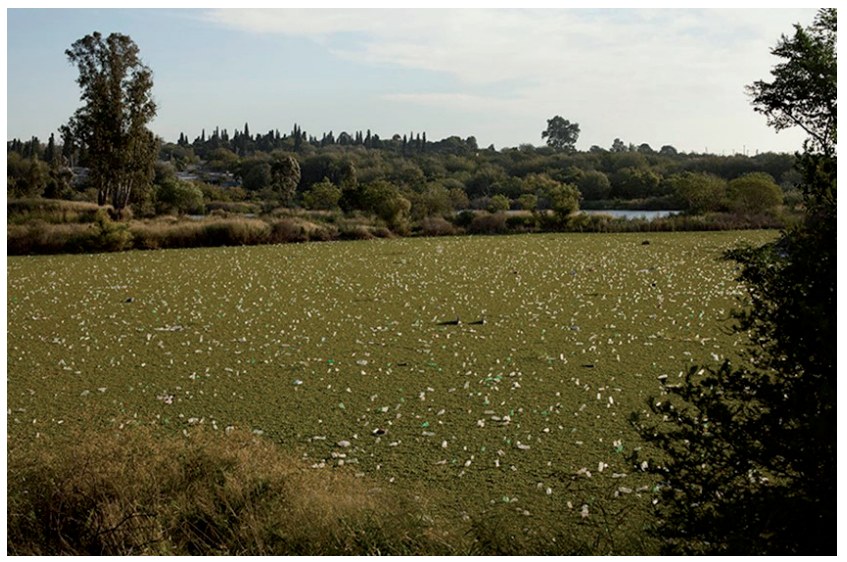

Gabriel Orge, 2012

En el video realizado por Cecilia Pasquini, en el que se narra la experiencia pedagógica realizada en la escuela, el procedimiento es que los niños eligen una de las fotografías, realizan un dibujo y explican su trabajo. En este caso, sin indagar con mayor profundi-

19 Anteriormente referida.

20 (Ver Figura 4). 
dad la situación pedagógica áulica ${ }^{21}$, nos centraremos en las elaboraciones, interpretaciones, representaciones y expresiones de los niños en relación con la obra de Orge.

En la reflexión sobre dos de sus fotografías -las cuales vemos a continuación- resulta clave la deriva "vital" que promueven los niños, "emocionados" por estas imágenes de la destrucción, de las cuales surgen (a partir de figuras y sensaciones arcaicas) imágenes de los arquetipos jungianos más primarios (ya elaborados a nivel del pensamiento) ${ }^{22}$ : el refugio, la casa, el abrigo; ligados a la sensación de seguridad y cobijo que necesitamos para vivir digna y amorosamente. Dos menciones se enfocan en la imagen de la pareja que vive en una casilla muy precaria (ver Figura 5), de dos metros cuadrados, en una zona de las sierras: una de las nenas refiere a "una pareja pobre", que vive "detrás de un country"; y dice: "no me gusta"; alude a los niños que tienen que "hurgar en los basureros para juntar comida", y "eso está mal"; otra de las niñas menciona que esta pareja "vive en una casita pobre en medio del bosque" y se dedica a "cortar árboles para ganar dinero".

En su dibujo, una de las nenas los representa con caras felices, fondo rojo y verde, rayado: les cambia radicalmente la expresión, no obstante en su registro conceptual la situación es triste (pero su imagen visual inscribe otro sentido y otra temporalidad propias del imaginario mágico: probablemente es el futuro proveniente del deseo que constituye un contra-fuego, y puede desatar tempestades y sublevaciones para apagar todo impulso y poder violento y doloroso).

En relación con la construcción de edificios y buildings inmobiliarios en torres de grandes empresas constructoras (ver Figura 6), un niño menciona "que los hacen muy rápido", que "construyeron muchas casas en su barrio, porque la gente necesita un lugar para vivir"... pero "debería haber un patio lo suficientemente grande para que haya más espacio verde, y ahí se pueden plantar flores, semillas, girasoles... muchas plantas se pueden plantar, y también se puede poner una mascota."

La belleza de esta imagen del niño que piensa puras imágenes contrastantes con el asedio de la urbanización frente a la naturaleza en peligro, imaginando una casa pequeña llena de flores y con un perro o un gato, basta para comprender la calidez del ensueño infantil en relación con situaciones de hogar que llenan de luz el habitar del mundo humano, con pocos y escasos elementos vitales que colman el afecto cotidiano.

Abierta la sensibilidad de los niños a sus emociones más primarias, los mismos producen contra-imágenes que enfrentan la marea destructiva (pudiendo conceptualizar la problemática en el diálogo y análisis verbal junto a sus compañeros y maestras, pero presentando una contra-imagen: en un caso, en la representación gráfica que cambia el sentido o el destino de las personas (a las que se les pone grandes sonrisas); o bien en la propia semántica lingüística, que no describe la imagen "tal cual es" o "como se ve" (lo cual sí realiza referencialmente en el dibujo el niño), sino que elabora una imagen

21 Por cuestiones de extensión, trabajaremos en el desarrollo del análisis de esta experiencia en un próximo texto, mostrando aquí una primera aproximación a diversas producciones a las que dio lugar la obra a partir de sus diferentes exhibiciones (Museo Caraffa, 2012; Fotogalería de la Casona Municipal, 2013). Los niños son de 3er. grado de educación primaria, es decir que tienen alrededor de 8 años.

22 Según la conceptualización que retoma Bachelard de Jung. También encontramos aquí, dentro de las imágenes materiales de la intimidad, figuraciones de la tierra, la raíz, el árbol, el laberinto, la gruta, la serpiente (a partir de los elementos vitales primitivos). 
deseada, que debería ser. En ambos casos, las narrativas de la experiencia se cruzan en la gravedad del análisis, pero toman formas diversas de expresión (en el marco de una elaboración colectiva situada en el aula escolar a partir del recorrido común de la muestra fotográfica, y su posterior cauce pedagógico). ${ }^{23}$

Dibujo de Aldana, una de las niñas de 3er. grado del Instituto de Educación Córdoba

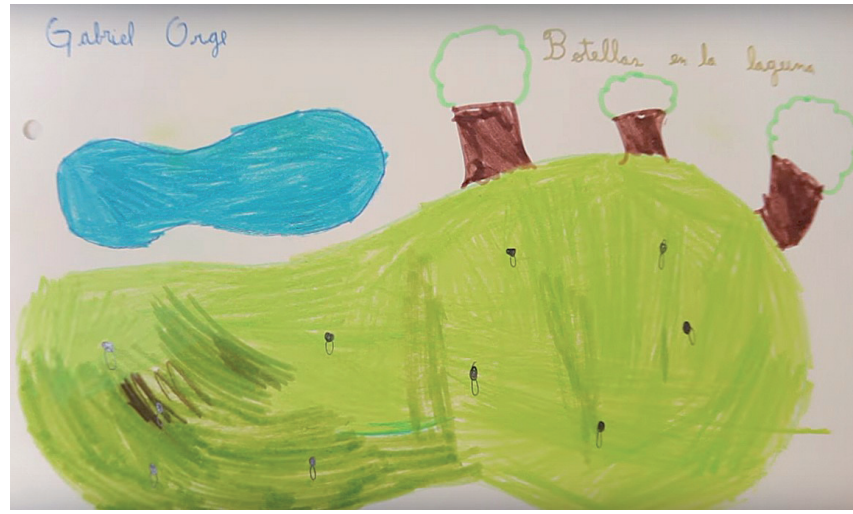

Figura 5 - De la Serie "Paisaje crítico": Pareja (zona noroeste de la ciudad de Córdoba)

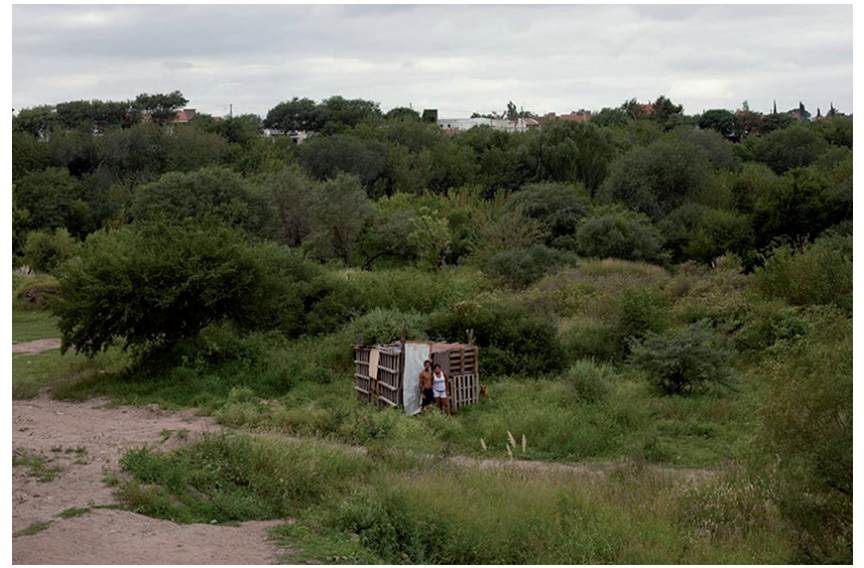

Gabriel Orge, 2012

23 Los dibujos de los niños a los que hacemos referencia pueden verse en el link, dentro del video que analizamos y del que hicimos mención con anterioridad. Los invitamos a hacer clic y conocer este hermoso trabajo: https://www.youtube. $\mathrm{com} /$ watch?v=wSdA4pcTrr0

Los alumnos le regalaron sus dibujos a Gabriel Orge, y Gabriel los comparte ahora con nosotros; al igual que nos ha permitido la reproducción de sus fotografías por este medio, lo cual le agradecemos muy especialmente. 
Figura 6 - De la Serie "Paisaje crítico": Edificios (negocio inmobiliario)

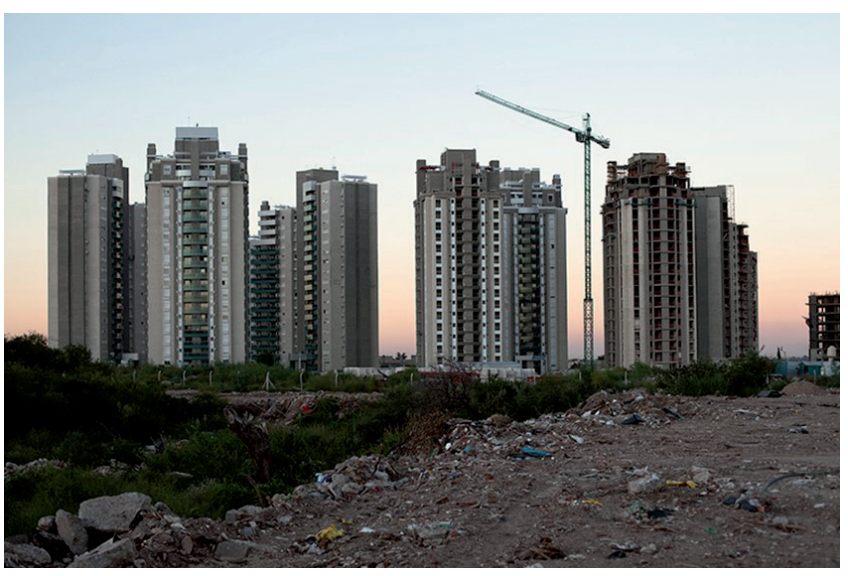

Gabriel Orge, 2012

\section{¿Se puede enseñar una afección o afectación?}

Una de las niñas dice: "Yo pienso que matar a la naturaleza está mal..." (los niños dibujan los "árboles en llamas" e interrogan "cómo es posible vivir así", en plena destrucción, desplegando argumentos y sentimientos cada vez más complejos y comprometidos con el presente y el futuro).

Barthes nos recuerda que la estructuración de los sentimientos se produce a partir de la división de la vida social ( $c f r$. Barthes, 2003), ordenando los sentidos del mundo de acuerdo con las configuraciones y valores centrales de los pueblos y culturas (más o menos igualitarios o desiguales, más o menos justos o injustos: más libres o más oprimidos por un poder que parece exterior a la humanidad). Por tanto, recuperar estas experiencias y percepciones en el trabajo cotidiano escolar y en la educación en las artes visuales resulta una clave sensible central para formar conciencia y sensibilidad hacia el cuidado de la naturaleza y las formas de vida sustentables de las comunidades humanas.

En un hermoso texto sobre cine e infancia, que se denomina "Niños atravesando el paisaje”, Jorge Larrosa (2006) analiza esta delicada relación entre la infancia y lo inefable. Retomando a Agamben, piensa la infancia del hombre, y no sólo el estadio de in-fans en la niñez (en tanto condición misma del lenguaje, marca la diferencia insalvable entre el lenguaje y lo humano, dada la imposibilidad originaria que coexiste con la vida del hombre: silencio, abismo del lenguaje, que no puede comprender ni nombrar las cosas más hondas). Así -afirma- lo inefable mismo es, en realidad, infancia (cfr. Larrosa, 2006: 117). ${ }^{24}$

24 Esta relación entre inefabilidad e infancia está muy presente también a lo largo de la obra de Barthes, en tanto insistencia escrituraria (o "verdad del cuerpo") que aparece en tanto imágenes vividas. En Incidentes, dice, en el hermoso texto llamado "La luz del Sudoeste" en el que describe biografemas de "los 3 sures" que le dan forma a sus tramas subjetivas más intensas: "Mi segundo Sudoeste no es un país; es solamente una línea, un trayecto vivido. Viniendo de París en auto (hice mil veces este viaje), cuando paso Angulema, una señal me advierte que traspuse el umbral de la casa y que entro al país de mi infancia; un bosquecillo de pinos sobre el costado, una palmera en el patio de una casa, cierta altura de las nubes que da al terreno la movilidad de un rostro. Comienza entonces la gran luz del sudoeste, noble y sutil al mismo tiempo; nunca gris, nunca baja (aunque el sol no reluzca); es una luz-espacio, definida no tanto por los colores con que afecta a las cosas [...] como por la cualidad eminentemente habitable que da a la tierra. No encuentro otro medio que decir: es una luz luminosa" (Barthes, 2016: 14) Y continúa: “... no busquen fotografiar demasiado; para juzgar, para amar, hay que venir y quedarse, de manera de poder recorrer toda la iridiscencia de los lugares, de las estaciones, de los tiempos, de las luces." (p. 15). 
Cuando un niño dice desesperadamente "no me gusta", y pensamos que le faltan palabras, nada nos acerca más a nuestra propia imposibilidad de nombrar injusticias, violencias y dolores cotidianos, y de comprender el mundo y poder transformarlo.

Ese rostro enigmático de la infancia de que hablaba Bazin puede funcionar y de hecho funciona como una problematización sensible de todos los estereotipos con los que hemos construido nuestra imagen de la infancia. Ese comportamiento puro de la infancia, gestualidad silenciosa de la que hablaba Agamben, puede funcionar y de hecho funciona como agujero negro en el que se abisman nuestras palabras, nuestros actos y nuestras mejores intenciones. Ese punto de vista infantil del que hablaba Wenders, ese estado de gracia que construye lo visible desde la altura de los ojos de niño, puede funcionar y de hecho funciona como una problematización sensible de nuestra propia mirada. $Y$ ese cara a cara a cara con la infancia puede funcionar, $\mathrm{y}$ de hecho funciona, como algo que nos está dirigido, $\mathrm{Y}$ exige una respuesta. (LARROSA, 2006: 120)

$\mathrm{Si}$, como lo analiza el autor, no hay nada más difícil que sostener la mirada de un niño y estar a la altura de esa mirada (cuyo reflejo nos impone la tragedia -y la responsabilidad- a la que estamos sometidos), justamente podemos pensar que, quizás, el gesto pedagógico más humano que podemos intentar sostener es el de captar lo limpio, la pureza, una ecología de imágenes -en el sentido de Fontcuberta, 2006-, volviendo a un cierto vacío que nos permita percibir, sentir y pensar un mundo nuevo menos contaminado, habitable.

Le toca al arte crítico, en tal sentido, cuestionar la superproducción, sobrecirculación y sobresaturación de imágenes e imaginarios livianos propios de la imaginería consumista del mundo capitalista global, vaciados de todo conflicto e interpretación: "imágenes sin huellas, sin sombras, sin consecuencias" (cfr. Larrosa, 2006: 104).

Superponerles imágenes diáfanas, directas (aunque dolorosas), que nos muestren las rasgaduras del mundo y sus "pliegues simbólicos", y no su complacencia, es quizás el punto central donde deben converger nuestras miradas y nuestra sensibilidad.

Buscando encontrar las sutilezas de la dialéctica social (y la división social del sentido) analizando estos espacios por cómo se clavan en la experiencia (y aquí refiere a su infancia en el contexto pequeño-burgués de la ciudad de Bayona -el interior provinciano, la casa de los abuelos-, donde pasó su infancia y su temprana adolescencia en medio de la austeridad económica y la pobreza que vivió en París), Barthes retorna a la memoria del cuerpo. "Mi cuerpo es mi infancia” (p. 16), dice, tal como la historia la hizo“... yo sentía esas sutilezas [...] Recorría el texto que va de la luz de un paisaje... a todo un tipo de discurso, social y provincial. Porque 'leer' un país es ante todo percibirlo según el cuerpo y la memoria, según la memoria del cuerpo.” (p. 18). Y continúa: “... a la edad en que se forma la memoria de las 'grandes realidades’ sólo tomé la sensación que me proporcionaban: olores, fatigas, sonidos de voces, carreras, luces, todo aquello de lo cual lo real es de algún modo irresponsable y no tiene otro sentido que formar más tarde el recuerdo del tiempo perdido (muy distinta fue mi infancia parisina: llena de dificultades materiales, tuvo, si se puede decir, la abstracción severa de la pobreza y, del París de esa época, casi no tengo 'impresiones')..." Entre sentidos clavados en el cuerpo y recuerdos clavados en la memoria (por placer y por saber), Barthes junta los cristales narrativos de la verdad viva de su experiencia subjetiva. Ver este análisis de los grandes imaginarios que atravesaron su vida -junto al análisis de sus fotografías familiares- en Barthes por Barthes, 1996; sobre el análisis de la división social del deseo en los “tres jardines”, ver Enrico, 2017. 


\section{Precariedad y estallido / in-fans y memoria}

Las vidas precarias, tal como las conceptualiza Butler (2006), son sometidas a una separación, segregación y expulsión social que por un lado perpetúa y naturaliza condiciones de vida vulnerables, inhumanas e indignas -como en el caso de los campos de refugiados y poblaciones o comunidades migrantes, expuestos a un permanente "estado de excepción" en marcos de guerra, de violencia y de pobreza extrema-; y por otro lado sostienen un orden de vidas vivibles que se distingue de la gran masa indiferenciada en condiciones de precariedad y sufrimiento -que hormiguea desesperadamente en un cierto "inframundo" cotidiano- (cfr. Butler, 2006).

Esta idea de la "agitación del hormiguero" es pensada por Bachelard (2014) en tanto "disputas por la intimidad" en la que se definen "imágenes fundamentales" de su epistemología de la imaginación activista. Así, piensa un "hormiguero desamparado" tanto como un hormiguero en plena agitación y actividad. ¿Qué nos sugieren tales imágenes? Que los movimientos de querella o unión entre lo inerte y lo vivo implican voluntades de poder y hostilidad que han de implicarse y manifestarse claramente en la "fermentación" de la materia: "la fermentación es vida" (Bachelard, 2014: 76) y aparece o bien como estado en elaboración -por ejemplo, la resistencia- o bien como estallido que rompe, desgarra y transforma la materia misma. "La imaginación material, que hallaba su reposo en la imagen de una sustancia fija, encierra una especie de batalla de la sustancia agitada. Sustancializa un combate" (Bachelard, 2014: 78). ${ }^{25}$

Tanto como en Derrida, aparecen en el autor las figuras del lobo en el marco de un "bestiario" o "beluario" (noción que toma del francés belluaire y que en español constituye un neologismo formado a partir de la palabra antigua belua= bestia) “...en tanto animales que se revelan como metáforas de una psicología de la violencia, de la crueldad, de la agresión [...] Ese bestiario no es un simbolismo inerte." (Bachelard, 2014: 79). Se refiere aquí Bachelard al "combate de sustancias" en las relaciones entre el campo de la alquimia y los metales; y nos interesa pensar este tipo de efectos materiales "devoradores" de unas "sustancias" o "cosas" sobre otras en muchos otros espacios de la realidad contemporánea (hoy, los agroquímicos envenenando tierras, sembrados y poblaciones, por dar un ejemplo de extrema gravedad en relación con sus consecuencias destructivas

25 Por su parte -para agregar otras lecturas a estas mitologías- Barthes sostiene, "sobreimprimiendo los fantasmas" (de los discursos de la historia, las culturas, las ciencias) al análisis social, que no es posible "comparar" ni inducir de un orden a otro, simple y directamente, rasgos de etología animal y rasgos de sociología humana -en tanto, por mencionar una cualidad distintiva fundamental, los seres humanos poseemos lenguaje, inteligencia y lazos "aprendidos" (culturales) que no existen en el paradigma animal en general, por lo cual las series terminan disociadas o bifurcadas en el orden de los vertebrados, al menos-. No obstante esta distinción, afirma que la etología animal nos provee de "visiones" para analizar el funcionamiento de las sociedades humanas. Y aquí justamente menciona el "mito banal" de la "sociedad-hormiguero" (en tanto forma de existencia típica del régimen capitalista moderno, caracterizada por un funcionamiento burocrático generalizado que genera indistinción, alienación y mecanización de funciones sociales, etc., debilitando a los sujetos) frente a la visión "más terrible" del "banco de peces", caracterizada por "traslaciones colectivas, sincrónicas y bruscas de gustos, placeres, modos, miedos" (Barthes, 2003: 84). Bajo este ritmo se produce el adiestramiento de los afectos, "enteramente igualados" en esta servidumbre y, por ende, la anulación total de los sujetos (lo cual es un efecto peor que la debilidad). Aquí es donde aparece la fundamental dimensión de la política, dice el autor: "preservar al sujeto", con todas sus pasiones y sus investiduras simbólicas, sociales y libidinales, éticas y memoriales (y no necesariamente "defender a los individuos" -en tanto cosas o entidades sin deseo o sin otros-). 
-pensando en particular en el sembrado de soja que fotografía Orge- ${ }^{26}$ donde el hormigueo y la destrucción no se ven pero acontecen silenciosamente).

Como en el caso de la cualidad de "rapidez" en la hostilidad de la animalidad del lobo (porque sin dudas el animal tiene muchísimas otras cualidades hermosas y no hostiles), ocurre que esta "rapidez" devoradora no permite el registro "en imágenes" (actúa sigilosamente, en silencio, casi de modo "in-visible"); pero ante las huellas, allí donde las imágenes de la destrucción en su acto mismo "se han ido", "nos quedan las palabras", dice Bachelard. Entonces debemos reconstruir palabra tras palabra e indicio tras indicio (mediante insistentes acciones pedagógicas de conciencia y memoria colectiva) las invisibles secuencias y acciones de la destrucción (que en este caso no se muestran ostensivamente sino que, por el contrario, aparecen ocultas, o bien visibles pero naturalizadas). ${ }^{27}$

En esta difícil convivencia entre los elementos del mundo podemos encontrar todas las imágenes de las pasiones humanas en la lucha entre animus y anima, entre agua y fuego, entre afinidad y hostilidad y entre armonía y destrucción (que son todos opuestos), en la pugna a muerte entre sustancias materiales vivientes y devorantes que se produce por debajo del mundo manifiesto, como un magma de enfrentamientos. "Sería un largo problema encontrar toda una química sentimental que nos hiciera determinar nuestra turbación íntima mediante imágenes en el corazón de las sustancias. Pero esa extraversión no sería en vano. Nos ayudaría a poner nuestras tristezas 'afuera', a hacer que nuestras tristezas funcionaran como si fueran imágenes." (Bachelard, 2014: 80). En esta línea de búsqueda del contacto social -que implica una elaboración afectiva- mediante la externalización de los sentimientos, el autor sostiene que "La intermediación de la imagen material es indispensable para encontrar las raíces oníricas de la expresión de la tristeza que corroe un corazón." (Bachelard, 2014: 80) ${ }^{28}$ Este método propone una exteriorización y una elaboración colectiva de las pasiones, y problematiza sus efectos sobre el alma humana y sobre la vida de la comunidad.

Ahora, en el marco de la presente reflexión, no olvidemos la sentencia filosófica: también somos lobos y la destrucción deviene en gran medida de decisiones humanas. "Homo homini lupus". Recordemos que Hobbes adopta esta locución latina en De Cive (Del ciudadano), en el siglo XVII (1642): "El hombre es lobo del hombre" (dando origen a toda una corriente de la teoría política moderna que atraviesa el Leviathan). En su obra Asinaria, Plauto, comediógrafo latino, (254 - 184 a. c.) afirma: "Lobo es el hombre para el hombre, y no hombre, cuando desconoce quién es el otro.”

\footnotetext{
26 (Ver Figura 1).

27 (Ver Figuras 1 y 4 ).

28 Los resaltados son del autor.
} 


\section{El hombre lobo del hombre, la cárcel del mundo, la rebelión silenciosa (metáforas finales) ${ }^{29}$}

En su libro “De A para X. Una historia en cartas”, John Berger nos comparte la historia de encierro de un terrorista mediante su intercambio de cartas con su amada. Berger transcribe "en un tipo más silencioso", respetando la escritura del reverso que realiza Xavier en las cartas que le envía A' ida -a modo de lecturas marginales de las cartas de amor recuperadas, las cuales no tienen fechas exactas ${ }^{30}$ notas hechas por Xavier en el mismo papel (el otro lado) de las cartas recibidas. Xavier transcribe escenas del daño global que funcionan como contexto epocal de inscripción y situación -literaria- de una tragedia que tiñe nuestra existencia (de la cárcel a la ciudad) de forma atemporal pero situable en cualquier punto del mundo: imágenes del manto de miedo de una destrucción total y masiva que puede ocurrir aquí mismo, mañana, ahora mismo incluso, en este mismo sitio y en todas partes (el mensaje es poder transmitir, "desde la cárcel" o el encierro -allí donde uno "no puede ver"-, lo que está sucediendo silenciosamente y en todas partes a la vez, en el exterior). No obstante el espesor del drama frente a esta tragedia total, siempre es pensable una salida, aún en condiciones de vida infrahumanas. "No es que tengamos esperanza -dice X- sino que la albergamos".

A' ida le escribe a Xavier:

Apenas queda un rato de oscuridad. Todavía no he dormido. Pensaba en el futuro. No en cualquier futuro en cualquier parte. Ni en nuestro futuro juntos. Pensaba en el futuro que intentan abortar aquí. No lo lograrán. El futuro que ellos temen llegará. Y lo que quedará en él de nosotros es la confianza que mantuvimos en la oscuridad. (BERGER, 2009: 89)

$\ldots$

En una de sus notas en el reverso de las cartas de A, dice Xavier (en esta tipografía "más silenciosa" en que lo transcribe y nos lo comparte Berger):

29 Dice Bachelard: "Sin duda estamos acostumbrados a este juego de inversión que coloca el realismo de la imagen ya sea en el hombre, ya en el universo. Pero no decimos bastante que es precisamente ese juego de inversión lo que constituye la dinámica de la imaginación. Mediante ese juego nuestro psiquismo cobra vida. Constituye una suerte de metáfora total que transpone los dos términos filosóficos del sujeto y del universo." (Bachelard, 2014: 222)

30 Narra Berger que "al abrirse una nueva cárcel de alta seguridad en Suse" (la localización es extraña: hay seis lugares -ciudades- en el mundo con el nombre "Suse": en Colombia, Azerbaiyán, Bosnia-Herzegovina, Corea del Sur, y dos en Zambia)... Al abrirse esta nueva cárcel "en los cerros que se extienden hacia el norte de la ciudad", la antigua cárcel quedó abandonada (la misma se encontraba en un edificio del centro). En la celda número 73 se hallaron una cantidad de cartas manuscritas ordenadas en paquetes en una especie de casilleros hechos con cajas de cigarrillos, asidos a la pared, dirigidas a "Xavier" (quien fuera el último habitante de esta celda, acusado de ser el fundador de una red terrorista, condenado a cumplir dos cadenas perpetuas). Las cartas estaban fechadas por día y por mes, pero no por años, y "al leerlas queda claro que no estaban ordenadas cronológicamente". Berger respetó el orden en que fueron encontradas, es decir, el orden en que fueron clasificadas y ubicadas por el mismo Xavier, en un intercambio de correspondencias que duró muchos años. La única luz natural que entraba en la celda era la de una pequeñísima ventana circular inaccesible en lo alto de uno de los muros, en la celda de dos metros y medio por tres, y cuatro metros de altura. Lo más interesante e intenso de este juego de cartas es que Berger incluye cartas "nunca enviadas por A'ida", de las cuales mantiene en secreto el modo en que llegaron a él, del mismo modo en que las intercala con las cartas sí enviadas (lo cual no podremos discernir y queda en el misterio); todas están escritas en el mismo papel azulado y no hacen referencia explícita al activismo político de A’ida. Encerrado Xavier, ellos no pudieron volver a verse, ni en la cárcel, ni afuera, ni nunca. 
Mil millones de personas no tienen acceso al agua potable. En algunas zonas de Brasil, un litro de agua comprada en la calle es más caro que un litro de leche; en Venezuela, más caro que un litro de gasolina. Al mismo tiempo, Botnia ${ }^{31}$ y Ence proyectan sacar del río Uruguay 86 millones de litros de agua diarios destinados a las papeleras de su propiedad. (BERGER, 2009: 18)

En otra de estas notas, dice:

El maestro (a quien uno de los guardias le rompió el otro día las gafas) nos citó esto: "Entre las cosas más bonitas que ya no vemos están la luz del sol, las estrellas rutilantes en una noche oscura, la luna llena y las frutas del verano: las peras, las manzanas, los pepinos maduros". Escrito ayer mismo, como si dijéramos, añadió el maestro, hace tan sólo dos mil quinientos años. (BERGER, 2009: 38)

No es casual que en este recuerdo se expresan al menos dos formas de violencia hacia la "figura" del maestro (que podemos ser todos, como en este caso un preso, un preso político, o cualquier preso, o cualquier ser humano: quien mira y quien recuerda). Una violencia física, literal (contra un cuerpo y contra un saber); y una violencia hacia "la belleza que ya no existe", citada por el maestro como un recuerdo del pasado, perdido quizás para siempre.

Asidos a esta belleza -compuesta por materia y memoria, como dice Bergson; cuerpo y alma ${ }^{32}$ - no permitiremos su muerte. Desde una mirada que incluye la imaginación del pensamiento tanto como la de los sueños, en una doble perspectiva de elementos conscientes e inconscientes, es necesario abrir y cerrar los ojos para entrar en las sensaciones de la profundidad del mundo y en los maravillosos misterios (indescifrables) de la naturaleza y la cultura -como un mismo territorio que tendrá su fin en una "noche de ultranegro" que ha de llegarle algún día-.

Esta "perspectiva maravillada" (Bachelard, 2014) ante semejante tesoro nos acerca a las formas y potencias impresionantes de todo lo viviente. Retomando el poema de Joe Bousquet que piensa la noche de ultranegro, "noche viviente y voraz a la que todo lo que respira está interiormente ligado", el cuerpo busca la trascendencia de esta noche-fenómeno, que es mucho más que la materia nocturna: "Es la noche de antes de la carne y le da a los hombres esos ojos en forma de flor cuyo color mineral y fascinante tiene sus raíces en la misma oscuridad que las plantas, las cabelleras, el mar." (Bousquet en Bachelard) "Antes de la carne y no obstante dentro de una carne, precisamente en los limbos carnales en que la muerte es resurrección, en que los ojos florecen de nuevo, asombrados..." (Bachelard, 2014: 197)

\footnotetext{
31 Empresas privadas multinacionales de producción de celulosa, de capitales extranjeros españoles y finlandeses respectivamente. Sobre la ex ENCE - Botnia (hoy “Orion”) un informe ambiental de 2016 -luego de al menos 8 años de conflicto y denuncias por contaminación y daño ambiental, para frenar la instalación de ambas plantas- constata "contaminación en el río Uruguay (en las márgenes de Argentina y Uruguay) y en la desembocadura del río Gualeguaychú”. Ambas cancillerías difundieron un resumen del documento -que consta de 400 páginas- "sin dar precisiones sobre las dimensiones de la contaminación" (luego de expedirse el Tribunal Internacional de La Haya unos años atrás). Entre otros puntos, se expresa, según lo menciona una nota periodística, que en los resultados analizados en el río Gualeguaychú: “... se superó el límite en la presencia de aluminio, amonio, atrazina, berilio, cadmio, fenoles totales, hidrocarburos aromáticos policíclicos, hidrocarburos del petróleo, hierro, magnesio y níquel." Fuente: https://www.cronista.com/economiapolitica/Botnia-un-informe-confirma-contaminacion-en-rios-Uruguay-y-Gualeguaychu-20161102-0111.html. Copyright@www.cronista.com (Nota del 02/11/2016; consultada el 22/03/2018). nes; y sobre la relación entre alegría y creación, ver las nociones de materia, percepción y memoria en Bergson (2013).
} 
Materia y memoria configuran, así, este mundo: la belleza que hemos perdido y la esperanza que albergamos como un refugio de la intemperie.

\section{Referencia}

ANTONELLI, M. "Violencia contemporánea. Ensayos para comprender y visibilizar nuestra condición”. En BOCCARDI, F.; BORIA, A.; HARRINGTON, C. (Comps.). Genealogías de la violencia. Editorial del CEA - UNC, Colección Libros: Debates, pensadores y problemas socioculturales, Córdoba. 2016.

BACHELARD, G. La tierra y las ensoñaciones del reposo. Ensayo sobre las imágenes de la intimidad. Colección Brevarios, Ed. Fondo de Cultura Económica, México. 2014.

BARTHES, R. Cómo vivir juntos. Simulaciones novelescas de algunos espacios cotidianos (notas de cursos y seminarios en el Collége de France, 1976-1977). Siglo XXI Editores, Argentina. 2003.

Barthes, R. Incidentes. La marca Editora, Colección biblioteca de los confines, Buenos Aires. 2016.

BENJAMIN, W. Sobre la fotografía. Ed. Pretextos, Valencia. 2007.

BERGER, J. De A para X. Una historia en cartas. Ed. Alfaguara, Buenos Aires. 2009.

BERGSON, H. Materia y memoria. Ensayo sobre la relación del cuerpo con el espíritu. Ed. Cactus, Serie Perenne, Buenos Aires. 2013.

BORIA, A. “Comprender la violencia en el mundo contemporáneo”. En BOCCARDI, F.; BORIA, A.; HARRINGTON, C. (Comps.). Genealogías de la violencia. Editorial del CEA - UNC, Colección Libros: Debates, pensadores y problemas socioculturales, Córdoba. 2016.

BUTLER, J. Vida precaria. El poder del duelo y la violencia. Ed. Paidós, Buenos Aires. 2006.

DERRIDA, J. Seminario La bestia y el soberano. Vol. 1 (2001 - 2002). Ed. Bordes - Manantial, Buenos Aires. 2010

ENRICO, J. "Cuerpos, lenguajes y poéticas subjetivas. Aportes de la translingüística barthesiana para pensar la experiencia biográfica (y las derivas de la identidad) en clave cultural, educativa e histórica”. En Del prudente saber. Año XVI - No 9 (2015-2016). Publicación de Investigadores - Facultad de Ciencias de la Educación de la Universidad Nacional de Entre Ríos, Paraná. 2017.

FONTCUBERTA, J. La furia de las imágenes. Notas sobre la postfotografía. Ed. Galaxia Gutenberg, Barcelona. 2016.

KRISTEVA, J. El tiempo sensible. Proust y la experiencia literaria. Ed. Eudeba, Buenos Aires. 2005.

LARROSA, J. "Niños atravesando el paisaje. Notas sobre cine e infancia”. En DUSSEL, I.; GUTIÉRREZ, D. Educar la mirada. Políticas y pedagogías de la imagen. Ed. Manantial - FLACSO - Fundación OSDE, Buenos Aires. 2006.

MADERUELO, J. Paisaje y arte. (Pensar el paisaje $N^{\circ}$ 2). Ed. Abada, Madrid. 2007.

SERRA, S. "Cine e impresiones educativas". En Frigerio, Graciela y Diker, Gabriela (Comps.). Educar: (sobre)impresiones estéticas. Serie Seminarios del CEM - Ed. Fundación La Hendija, Paraná. 2012.

TERIGI, F. "Nuevas reflexiones sobre el lugar de las artes en el curriculum escolar”. En Frigerio, Graciela y Diker, Gabriela (Comps.). Educar: (sobre)impresiones estéticas. Serie Seminarios del CEM - Ed. Fundación La Hendija, Paraná. 2012.

Recebido em 10 de abril de 2018.

Aceito em 20 de maio de 2018. 